\title{
TU/e emonownen

\section{Remote plasma atomic layer deposition of thin films of electrochemically active LiCoO2}

\section{Citation for published version (APA):}

Donders, M. E., Knoops, H. C. M., Kessels, W. M. M., \& Notten, P. H. L. (2011). Remote plasma atomic layer deposition of thin films of electrochemically active LiCoO2. ECS Transactions, 41(2), 321-330.

https://doi.org/10.1149/1.3633683

DOI:

10.1149/1.3633683

Document status and date:

Published: 01/01/2011

\section{Document Version:}

Publisher's PDF, also known as Version of Record (includes final page, issue and volume numbers)

\section{Please check the document version of this publication:}

- A submitted manuscript is the version of the article upon submission and before peer-review. There can be important differences between the submitted version and the official published version of record. People interested in the research are advised to contact the author for the final version of the publication, or visit the $\mathrm{DOI}$ to the publisher's website.

- The final author version and the galley proof are versions of the publication after peer review.

- The final published version features the final layout of the paper including the volume, issue and page numbers.

Link to publication

\section{General rights}

Copyright and moral rights for the publications made accessible in the public portal are retained by the authors and/or other copyright owners and it is a condition of accessing publications that users recognise and abide by the legal requirements associated with these rights.

- Users may download and print one copy of any publication from the public portal for the purpose of private study or research.

- You may not further distribute the material or use it for any profit-making activity or commercial gain

- You may freely distribute the URL identifying the publication in the public portal.

If the publication is distributed under the terms of Article 25fa of the Dutch Copyright Act, indicated by the "Taverne" license above, please follow below link for the End User Agreement:

www.tue.nl/taverne

Take down policy

If you believe that this document breaches copyright please contact us at:

openaccess@tue.nl

providing details and we will investigate your claim. 


\title{
Remote Plasma Atomic Layer Deposition of Thin Films of Electrochemically Active $\mathrm{LiCoO}_{2}$
}

\author{
M. E. Donders ${ }^{\mathrm{a}, \mathrm{b}}$, H. C. M. Knoops ${ }^{\mathrm{a}, \mathrm{b}}$, W. M. M. Kessels ${ }^{\mathrm{b}}$, and P. H. L. Notten ${ }^{\mathrm{b}}$ \\ ${ }^{a}$ Materials innovation institute M2i, P.O. Box 5008, 2600 GA Delft, Netherlands \\ ${ }^{\mathrm{b}}$ Eindhoven University of Technology, P.O. Box 513, 5600 MB Eindhoven, Netherlands
}

\begin{abstract}
One of the remaining challenges in the field of portable electronics is the miniaturization of lithium-ion batteries without decreasing their storage capacity. To tackle this challenge and to effectively integrate battery technology in even a wider variety of applications, it is essential to produce high quality thin films for all-solid-state batteries. A remote plasma ALD process for the positive electrode material $\mathrm{LiCoO}_{2}$ was developed using the combination of $\mathrm{CoCp}_{2}$ as the cobalt precursor, $\mathrm{LiO}^{t} \mathrm{Bu}$ as the lithium precursor and $\mathrm{O}_{2}$ plasma as the oxidant source. The thin films were deposited at a temperature of $325{ }^{\circ} \mathrm{C}$ with a virtually linear growth rate of $0.06 \mathrm{~nm} /$ cycle. After annealing the samples at $700{ }^{\circ} \mathrm{C}$ for 6 minutes the high temperature phase $\mathrm{LiCoO}_{2}$ was obtained, as demonstrated by XRD and Raman spectroscopy measurements. Electrochemical charge/discharge cycling showed good electrochemical activity with a promising storage capacity.
\end{abstract}

\section{Introduction}

During the past decade, portable electronic devices have become considerably more widespread, complex, and powerful and new challenges have been encountered, especially in terms of energy management. For powering the devices an energy source is required with a high energy-to-weight and high energy-to-volume ratio. Lithium-ion batteries can fulfil these demands and consequently are applied on a large scale. However, one of the remaining challenges in the field is the miniaturization of lithiumion batteries without decreasing the storage capacity. To tackle this challenge and to effectively integrate battery technology in even a wider variety of applications, 3Dintegrated all-solid-state batteries have been proposed in various publications (1-3).

One of the most commonly used positive electrode materials in present-day battery technology is the well-investigated lithium cobalt oxide $\left(\mathrm{LiCoO}_{2}\right)$ with a capacity of 155 $\mathrm{mAh} / \mathrm{g}$ (4). $\mathrm{LiCoO}_{2}$ has previously been deposited by radio frequency (RF) magnetron sputtering $(5,6)$, sol-gel processing (7), electron beam evaporation (8), spray pyrolysis $(6,9)$, pulsed laser deposition (PLD) (10) and (metal organic) chemical vapor deposition (CVD) (11,12). All these methods can produce high purity $\mathrm{LiCoO}_{2}$. However, for the aforementioned application it is essential to produce high quality thin films for all-solidstate batteries. Atomic layer deposition (ALD) presents a (sub) monolayer growth control 
by supplying the precursors to the reactor in alternating sequences, rather than simultaneously as in chemical vapor deposition (CVD). Due to the surface chemistry controlled deposition process, ALD is chosen in this work and provides an excellent conformality and thickness control at the atomic level, even in challenging high-aspectratio structures. Several lithium compounds have recently been deposited using ALD in the form of $\mathrm{LiOH}, \mathrm{Li}_{2} \mathrm{CO}_{3}$ and lithium lanthanum titanate $\left[(\mathrm{Li}, \mathrm{La})_{\mathrm{x}} \mathrm{Ti}_{\mathrm{y}} \mathrm{O}_{\mathrm{z}}(\mathrm{LLT})\right]$ films $(13,14)$, however no reports of electrochemical analysis of ALD deposited lithium containing materials are available to date. An overview of Li-based materials deposited by ALD as reported in the literature is shown in Table I. Also CVD processes for $\mathrm{LiCoO}_{2}$ are listed in the table.

In this paper the ALD process of $\mathrm{Co}_{3} \mathrm{O}_{4}(15)$ is combined with the process of $\mathrm{Li}_{2} \mathrm{CO}_{3}$ $(13,14)$ to deposit an electrochemically active battery electrode material $\left(\mathrm{LiCoO}_{2}\right)$ for the first time.

TABLE I. Overview of ALD processes for the deposition of lithium-containing compounds and CVD processes for $\mathrm{LiCoO}_{2}$.

\begin{tabular}{|c|c|c|c|c|c|c|c|}
\hline & $\begin{array}{c}\text { Deposited } \\
\text { material }\end{array}$ & $\begin{array}{l}\text { Lithium } \\
\text { precursor }\end{array}$ & $\begin{array}{c}\text { Other } \\
\text { Precursor(s) }\end{array}$ & Reactant(s) & $\begin{array}{l}\text { Deposition } \\
\text { temperature }\end{array}$ & Growth rate & References \\
\hline \multirow[t]{4}{*}{ ALD } & $\mathrm{Li}_{2} \mathrm{CO}_{3}$ & $\mathrm{LiO}^{t} \mathrm{Bu}$ & - & $\mathrm{H}_{2} \mathrm{O}$ & $225^{\circ} \mathrm{C}$ & $0.08 \mathrm{~nm} /$ cycle & 13,14 \\
\hline & LLT & $\mathrm{LiO}^{t} \mathrm{Bu}$ & $\begin{array}{l}\mathrm{La}(\mathrm{thd})_{3} \\
\mathrm{TiCl}_{4}\end{array}$ & $\begin{array}{c}\mathrm{O}_{3} \\
\mathrm{H}_{2} \mathrm{O} \\
\end{array}$ & $225^{\circ} \mathrm{C}$ & $0.05 \mathrm{~nm} /$ cycle & 14 \\
\hline & $\mathrm{LiOH}$ & $\mathrm{LiO}^{t} \mathrm{Bu}$ & - & $\mathrm{H}_{2} \mathrm{O}$ & $225^{\circ} \mathrm{C}$ & $0.09 \mathrm{~nm} /$ cycle & 13 \\
\hline & $\mathrm{LiCoO}_{2}$ & $\mathrm{LiO}^{t} \mathrm{Bu}$ & $\mathrm{CoCp}_{2}$ & $\mathrm{O}_{2}$ plasma & $325^{\circ} \mathrm{C}$ & $0.06 \mathrm{~nm} /$ cycle & This work \\
\hline \multirow[t]{2}{*}{ CVD } & $\mathrm{LiCoO}_{2}$ & ${ }^{t} \mathrm{BuLi}$ & $\mathrm{CpCo}(\mathrm{CO})_{2}$ & $\mathrm{O}_{2}$ & $300-600^{\circ} \mathrm{C}$ & - & 11 \\
\hline & $\mathrm{LiCoO}_{2}$ & Li(TMHD) & $\mathrm{Co}(\mathrm{TMHD})_{3}$ & $\mathrm{O}_{2} / \mathrm{N}_{2}$ & $450-550{ }^{\circ} \mathrm{C}$ & - & 12 \\
\hline
\end{tabular}

TABLE II. Overview of $\mathrm{LiCoO}_{2}$ ALD process parameters for the different sub-cycles of the super-cycle.

\begin{tabular}{lccccr}
\hline & $\begin{array}{c}\text { Precursor/ } \\
\text { reactant }\end{array}$ & Dosing time & $\begin{array}{c}\text { Pump purge } \\
\text { time }\end{array}$ & $\begin{array}{c}\text { Precursor } \\
\text { temperature }\end{array}$ & $\begin{array}{c}\text { Precursor line } \\
\text { temperature }\end{array}$ \\
\hline \hline $\mathrm{Co}_{3} \mathrm{O}_{4}$ & $\mathrm{CoCp} 2$ & $2 \mathrm{~s}$ & $3 \mathrm{~s}$ & $80{ }^{\circ} \mathrm{C}$ & $105^{\circ} \mathrm{C}$ \\
\cline { 2 - 6 } & $\mathrm{O}_{2}$ plasma & $5 \mathrm{~s}$ & $0.5 \mathrm{~s}$ & - & - \\
\hline \hline $\mathrm{Li}_{2} \mathrm{CO}_{3}$ & $\mathrm{LiO}^{\mathrm{t}} \mathrm{Bu}$ & $2 \mathrm{~s}$ & $3 \mathrm{~s}$ & $120^{\circ} \mathrm{C}$ & $150^{\circ} \mathrm{C}$ \\
\cline { 2 - 6 } & $\mathrm{O}_{2}$ plasma & $5 \mathrm{~s}$ & $0.5 \mathrm{~s}$ & & - \\
\hline \hline
\end{tabular}




\section{Experimental details}

\section{Film preparation}

The $\mathrm{LiCoO}_{2}$ films were deposited using a home-built open-load ALD reactor as described previously for the deposition of $\mathrm{Co}_{3} \mathrm{O}_{4}$ (15). In this setup an inductively coupled plasma (ICP) source is connected to a deposition chamber along with a pump unit through gate valves. The pump unit consists of a rotary and turbo molecular pump, which can reach a base pressure of $<10^{-5}$ Torr by overnight pumping. The $\mathrm{CoCp}_{2}$ and $\mathrm{LiO}^{\mathrm{t}} \mathrm{Bu}$ precursors (both $98 \%$, Strem Chemicals) were heated to $80{ }^{\circ} \mathrm{C}$ and $120{ }^{\circ} \mathrm{C}$ respectively (Table II) and they were bubbled with $\mathrm{Ar}$ at a reactor pressure of 0.02 Torr. The substrate was heated to $325{ }^{\circ} \mathrm{C}$, while the reactor walls, Ar lines, and $\mathrm{CoCp}_{2}$ precursor lines were maintained at a temperature of $105{ }^{\circ} \mathrm{C}$ and the $\mathrm{LiO}^{\mathrm{t}} \mathrm{Bu}$ precursor lines at $150{ }^{\circ} \mathrm{C}$ to prevent precursor condensation. $\mathrm{Si}(100)$ with native oxide and $\mathrm{Si}(100)$ with $400 \mathrm{~nm}$ thermally grown $\mathrm{SiO}_{2}$ were used as substrates for materials analysis. For electrochemical analysis $\mathrm{Si} / \mathrm{TiO}_{2} / \mathrm{Pt}$ substrates were prepared by ALD as described in an earlier publication and shown in Figure 2 (16).

The remote plasma ALD process for $\mathrm{LiCoO}_{2}$ consists of two individual ALD processes which are combined in a so-called super-cycle (Fig. 1). Here the previously described remote plasma ALD process for $\mathrm{Co}_{3} \mathrm{O}_{4}$ is combined with a novel ALD process using a lithium precursor reported recently for the deposition of LLT and $\mathrm{Li}_{2} \mathrm{CO}_{3}(13,14)$. In both processes a precursor dosing time of $2 \mathrm{~s}$ is applied combined with an $\mathrm{O}_{2}$ plasma at $100 \mathrm{~W}$ for $5 \mathrm{~s}$ at a pressure of 0.01 Torr. During and after the precursor dosing and plasma exposure, the reaction chamber is purged and then evacuated.
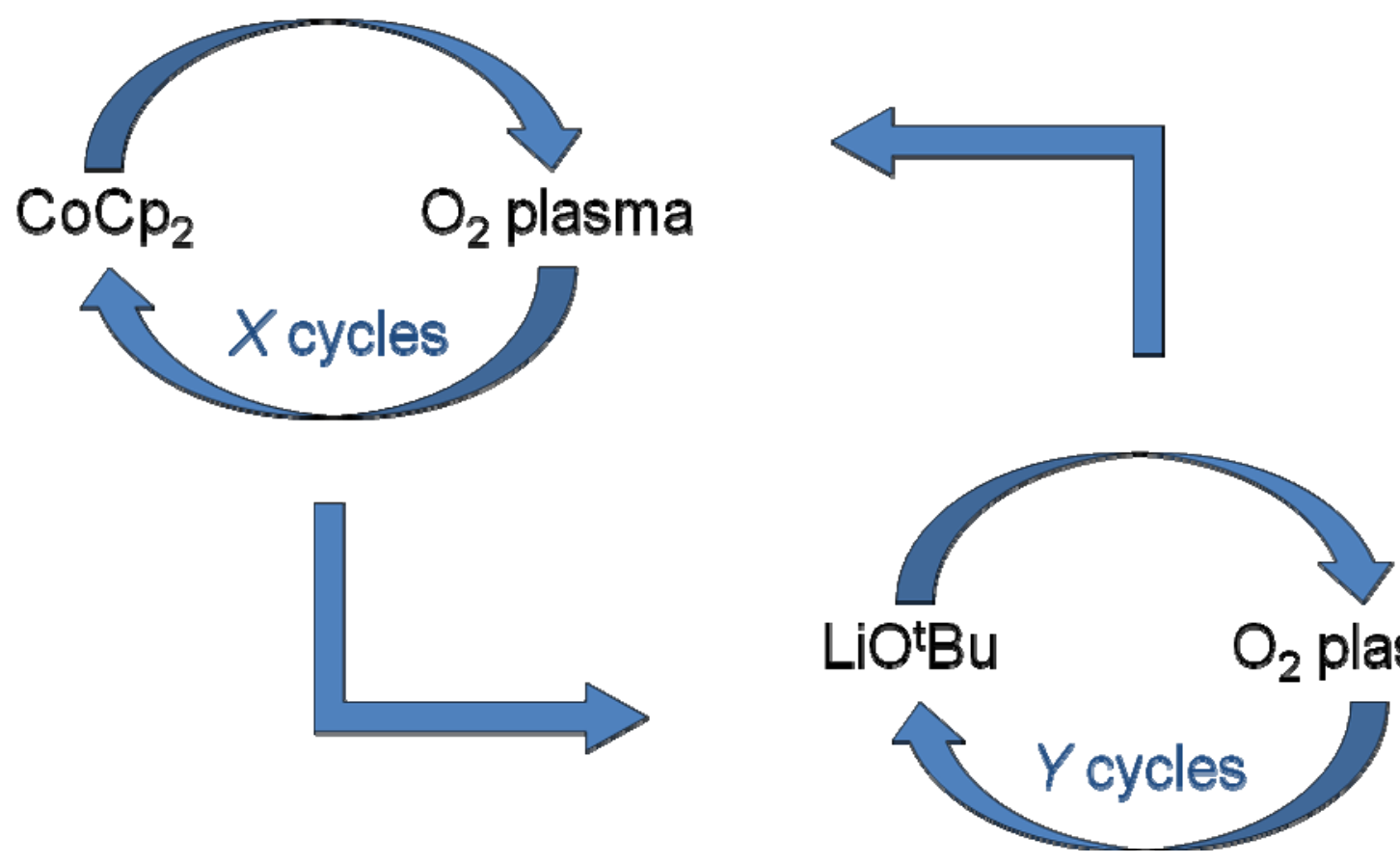

Figure 1: Schematic representation of an ALD super-cycle consisting of the two individual ALD processes for $\mathrm{Co}_{3} \mathrm{O}_{4}$ and $\mathrm{Li}_{2} \mathrm{CO}_{3}$. $X$ cycles of the $\mathrm{Co}_{3} \mathrm{O}_{4}$ process are alternated with $Y$ cycles of the $\mathrm{Li}_{2} \mathrm{CO}_{3}$ process. 


\section{Material analysis}

The thickness and dielectric function of the films were monitored during the ALD process by in situ spectroscopic ellipsometry (SE) with a J.A. Woollam, Inc. M2000U $(0.75-5.0 \mathrm{eV})$ ellipsometer (17). The optical range was extended to $6.5 \mathrm{eV}$ after the deposition process, using ex situ variable angle measurements with a J.A. Woollam, Inc. M2000D ellipsometer. The dielectric function of $\mathrm{Co}_{3} \mathrm{O}_{4}$ has been extracted from the SE measurements using an optical model employing a Gauss, a Tauc-Lorentz, and two Lorentz oscillators, to account for the absorption bands (15). The dielectric functions of $\mathrm{Li}_{2} \mathrm{CO}_{3}$ and $\mathrm{LiCoO}_{2}$ were parameterized using a mathematical description in the form of B-splines (18). This is a method that requires no prior knowledge about the dielectric function of deposited films and enables in situ thickness measurements.

The microstructure of the lithium cobalt oxide films was studied using Grazing Incidence X-ray diffraction (GI-XRD) with a Philips X'Pert MPD diffractometer equipped with a $\mathrm{Cu} \mathrm{K} \mathrm{K}_{\alpha}$ source (1.54 $\AA$ radiation). The Raman spectra of the samples were recorded using a micro Raman scattering setup (In-via Renishaw) with a resolution of 1.6 $\mathrm{cm}^{-1}$.

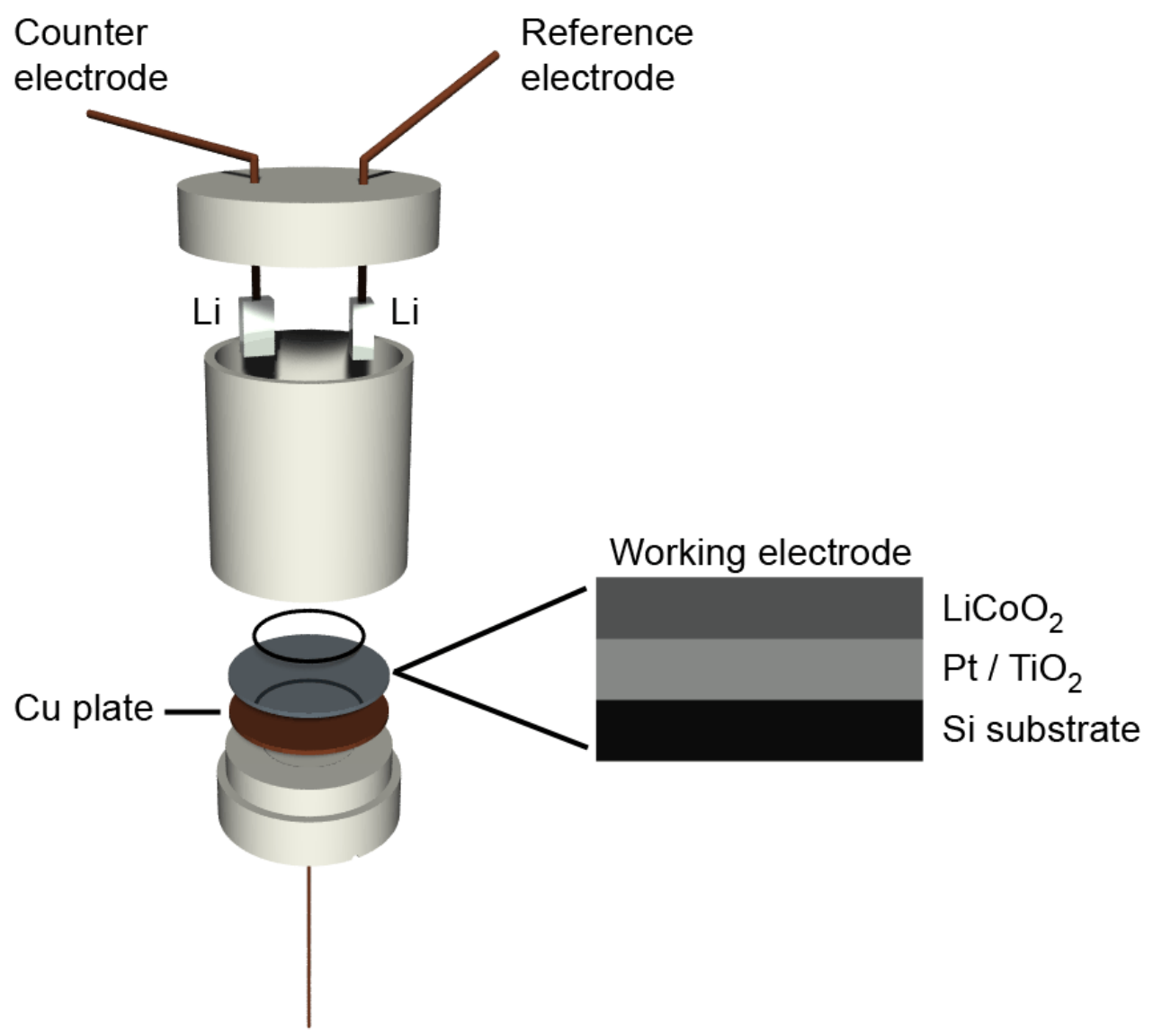

Figure 2: Schematic representation of the Teflon ${ }^{\circledR}$ three-electrode measurement setup in which the $\mathrm{LiCoO}_{2}$ on $\mathrm{Si} / \mathrm{TiO}_{2} / \mathrm{Pt}$ substrates are used as working electrode for the electrochemical measurements. 


\section{Electrochemical analysis}

The electrochemical analyses were performed in three-electrode cylindrical electrochemical cells with an effective measurement surface area of $2 \mathrm{~cm}^{2}$ (Fig. 2). The cells were made of Teflon ${ }^{\circledR}$ with a volume of about $15 \mathrm{ml}$. The cells were assembled in an argon-filled glove-box. The $\mathrm{LiCoO}_{2}$ electrodes were mounted as working electrodes and back-contacted with silver paint to facilitate a good electrical connection. Pure lithium foils were used as counter and reference electrodes. 1 molar $\mathrm{LiClO}_{4}$ dissolved in Ethyl Carbonate (EC)/Diethyl Carbonate (DEC) was used as liquid electrolyte (Puriel, Techno, Semichem Co., Ltd, Korea). The cells were placed in a stainless steel holder that was thermostatically controlled at room temperature. Contaminants in the glove-box (water and oxygen) were monitored and controlled below $1 \mathrm{ppm}$. Galvanostatic cycling was performed with a M2300 galvanostat (Maccor, Tulsa, USA). The following definition is adopted throughout the manuscript: discharging an electrode material refers to Li-ion insertion (or lithiation) and charging to Li-ion extraction (or delithiation).

\section{ALD growth}

\section{Results \& Discussion}

To investigate the ALD process parameters, the self-limiting behavior of the ALD process was investigated for the $\mathrm{CoCp}_{2}$ and $\mathrm{LiO}^{t} \mathrm{Bu}$ precursors using a $\mathrm{Co}: \mathrm{Li}$ dosing ratio of 1:1 for the supercycle as displayed in Fig. 1. The plasma exposure time was fixed at 5 seconds for both precursors. The Li precursor dosing time was varied while the Co dosing time remained constant at $2 \mathrm{~s}$, which is the same dosing time used during the deposition of $\mathrm{Co}_{3} \mathrm{O}_{4}$ (15). Saturation of the $\mathrm{Li}$ precursor is seen around $2 \mathrm{~s}$. The same procedure was conducted for the Co precursor while the Li dosing remained constant at $2 \mathrm{~s}$. Proper saturation behavior is observed for both cases as shown in Fig. 3a and 3b, however the obtained growth per cycle is different. The deviation in these measurements could be explained by the different starting thickness of the film, because the growth per cycle slightly changed throughout the growth process (Fig. 4). Dosing times of $2 \mathrm{~s}$ for both precursors are chosen as baseline conditions to ensure proper ALD conditions for all experiments presented below.
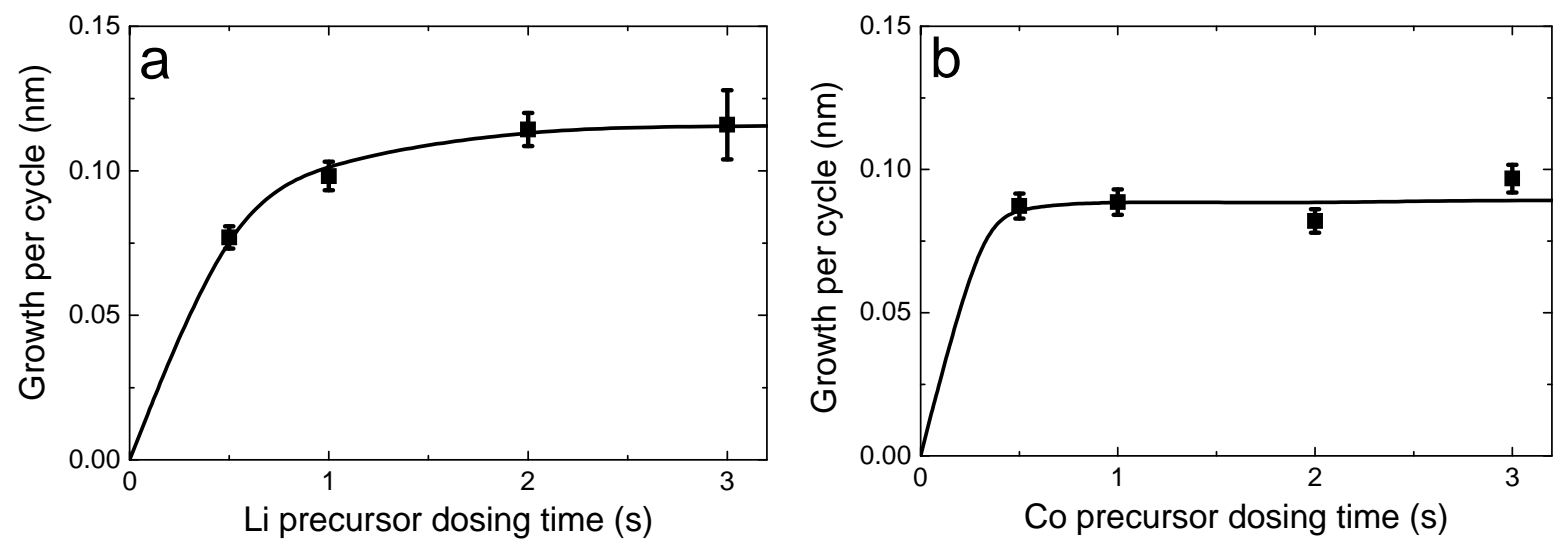

Figure 3: Saturation curves for remote plasma ALD of $\mathrm{LiCoO}_{2}$ at $325^{\circ} \mathrm{C}$ (a) Growth rate as a function of $\mathrm{LiO}^{\mathrm{t}} \mathrm{Bu}$ dosing time, while the $\mathrm{CoCp}_{2}$ dosing time and plasma exposure time are kept constant at $2 \mathrm{~s}$ and $5 \mathrm{~s}$ respectively. (b) Growth rate as a function of $\mathrm{CoCp}_{2}$ dosing time, while the $\mathrm{LiO}^{t} \mathrm{Bu}$ dosing time and plasma exposure time are kept constant at $2 \mathrm{~s}$ and $5 \mathrm{~s}$ respectively. The lines serve as guides to the eye. 


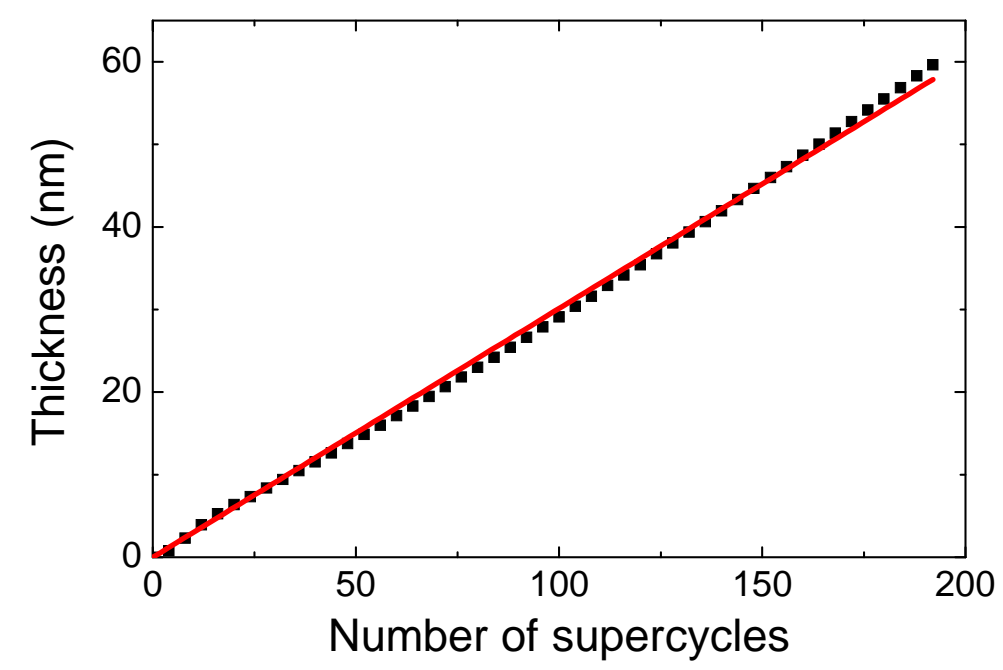

Figure 4. Thickness of $\mathrm{LiCoO}_{2}$ on $\mathrm{Si}(100)$ as a function of the number of ALD supercycles, as measured with in situ spectroscopic ellipsometry. The used Co:Li dosing ratio is 4:1.

Applying a Co:Li dosing ratio of 1:1 lead to a slightly higher growth rate than expected from the individual growth rates of $\mathrm{Co}_{3} \mathrm{O}_{4}$ and $\mathrm{Li}_{2} \mathrm{CO}_{3}$. This could be due to the high growth rate of $\mathrm{Li}_{2} \mathrm{CO}_{3}$ as compared to $\mathrm{Co}_{3} \mathrm{O}_{4}(13,15)$, but the growth of $\mathrm{Li}_{2} \mathrm{CO}_{3}$ could also be catalyzed by the presence of cobalt atoms. At a dosing ratio of Co:Li to 4:1 (Fig. 4) the thickness was virtually linear dependent on the number of ALD cycles and the overall growth rate was $\sim 0.06 \mathrm{~nm} /$ cycle. It is not expected that the change in Co:Li dosing ratio will significantly affect the saturation of either precursor. Figure 5 shows the dielectric function $\varepsilon_{2}$ of as-deposited $\mathrm{Co}_{3} \mathrm{O}_{4}, \mathrm{Li}_{2} \mathrm{CO}_{3}$ and $\mathrm{LiCoO}_{2}$ between $1.24 \mathrm{eV}$ and $6.5 \mathrm{eV}$ and a clear difference is seen between the three films. The dielectric function of $\mathrm{Co}_{3} \mathrm{O}_{4}$ has been described in an earlier publication (15), however not much is known in the literature about the dielectric functions of $\mathrm{Li}_{2} \mathrm{CO}_{3}$ and $\mathrm{LiCoO}_{2}$.

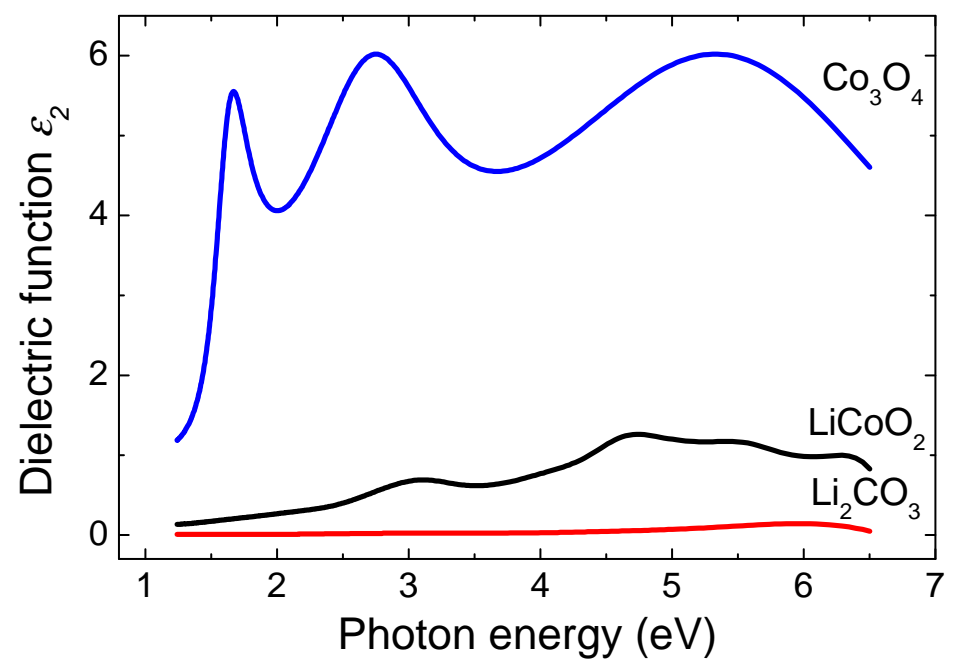

Figure 5. The imaginary part of the dielectric function $\left(\varepsilon_{2}\right)$ of the $\mathrm{Co}_{3} \mathrm{O}_{4}, \mathrm{Li}_{2} \mathrm{CO}_{3}$ and $\mathrm{LiCoO}_{2}$ films as determined by in situ spectroscopic ellipsometry. 


\section{Material properties}

To ensure a stoichiometric deposition of $\mathrm{LiCoO}_{2}$ a Co:Li dosing ratio of 2:1 was used to investigate the material properties. The obtained as-deposited samples were investigated by GI-XRD and Raman spectroscopy and subsequently annealed at $700{ }^{\circ} \mathrm{C}$ for 6 minutes before being measured again with the same techniques. In Fig. 6 a large diffraction peak becomes visible after annealing at a $2 \theta$ angle of $19^{\circ}$, which has also been reported in the literature for $\mathrm{MO}-\mathrm{CVD}$ deposited $\mathrm{LiCoO}_{2}$ at various temperatures (19). This peak can be assigned to both the (111) reflection of $\mathrm{Co}_{3} \mathrm{O}_{4}$ and the (003) reflection of $\mathrm{LiCoO}_{2}$. As both cobalt oxide and lithium cobalt oxide can be present in the deposited thin films it is not possible to unambiguously determine the origin of the diffraction peak and the nature of the film. Raman spectroscopy has therefore been used as shown in Fig. 7. The high temperature (HT) hexagonal phase $\mathrm{LiCoO}_{2}$ is observed with two typical phonon modes at 486 and $596 \mathrm{~cm}^{-1}$ which becomes even more defined after annealing (12). The Raman spectra reveal no significant fraction of $\mathrm{Co}_{3} \mathrm{O}_{4}$ in the films as this would lead to a peak at $693 \mathrm{~cm}^{-1}$.

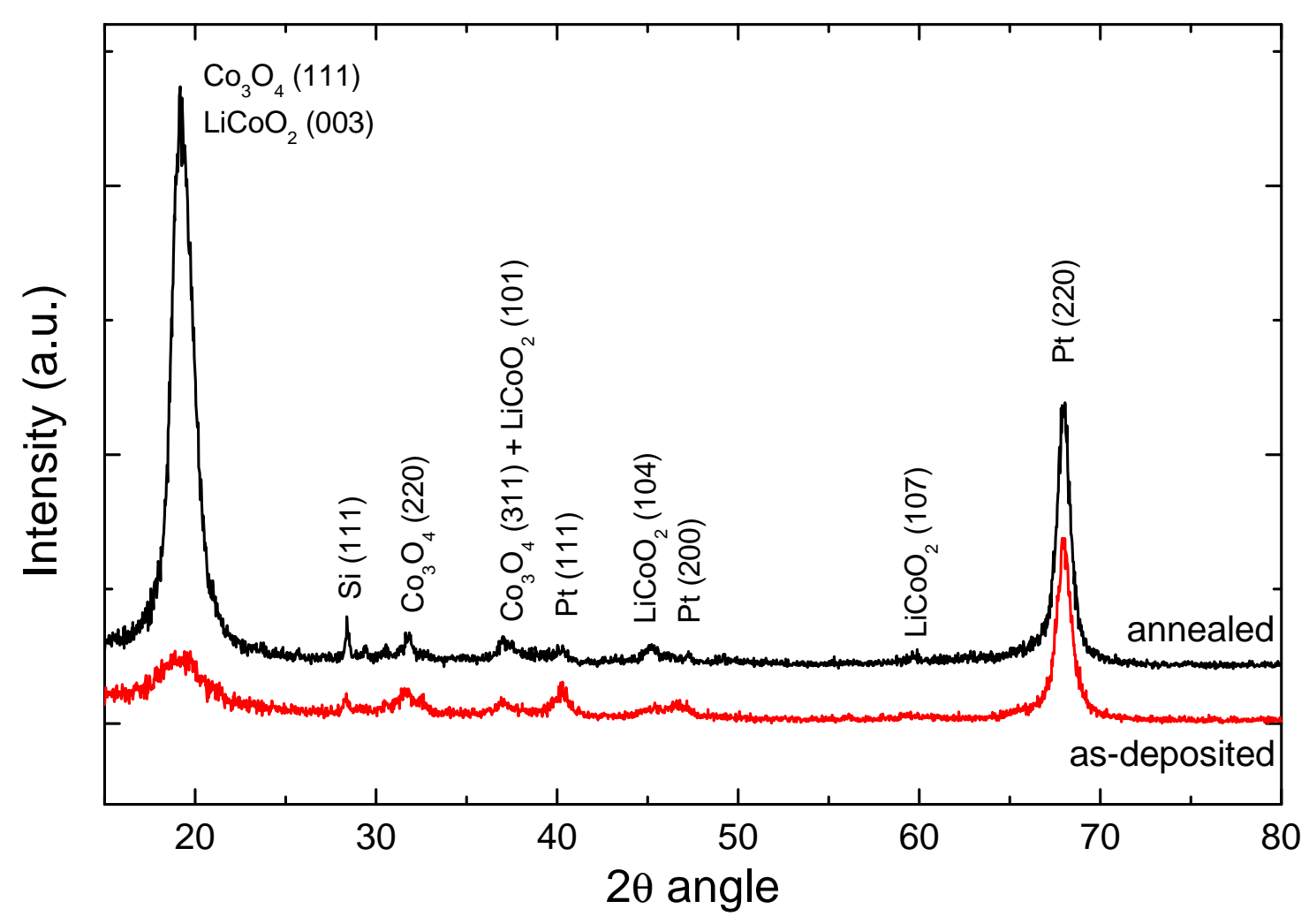

Figure 6: X-ray diffraction measurements $(\lambda=1.54 \AA)$ revealing overlapping peaks for $\mathrm{Co}_{3} \mathrm{O}_{4}$ with a preferential (111) orientation and crystalline $\mathrm{LiCoO}_{2}$ after annealing at $700{ }^{\circ} \mathrm{C}$ for 6 minutes. The spectra have been offset vertically for clarity. The Co:Li dosing ratio was 2:1. 


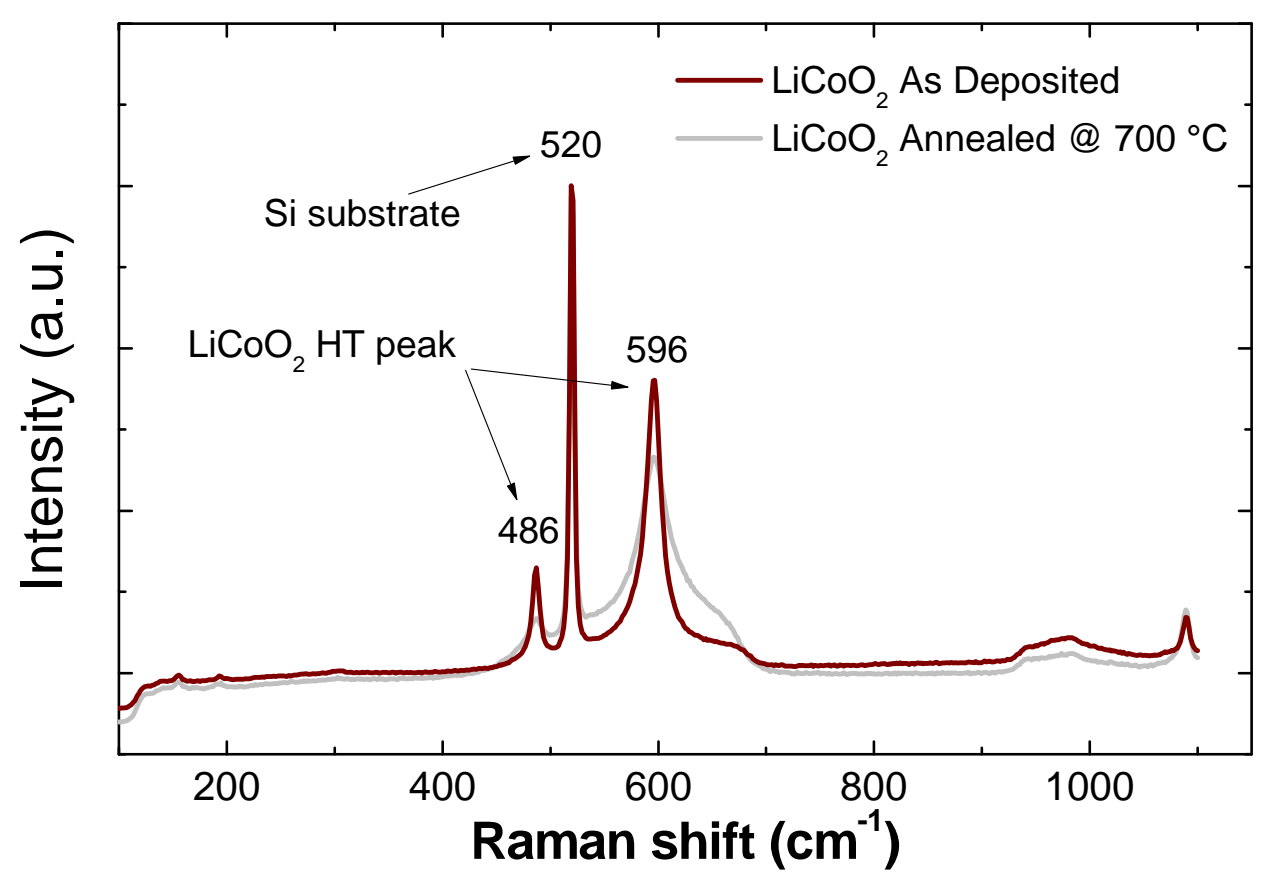

Figure 7: Raman measurements for $\mathrm{LiCoO}_{2}$ annealed at $700{ }^{\circ} \mathrm{C}$ for 6 minutes compared to as-deposited $\mathrm{LiCoO}_{2}$. The used Co:Li dosing ratio was $2: 1$.

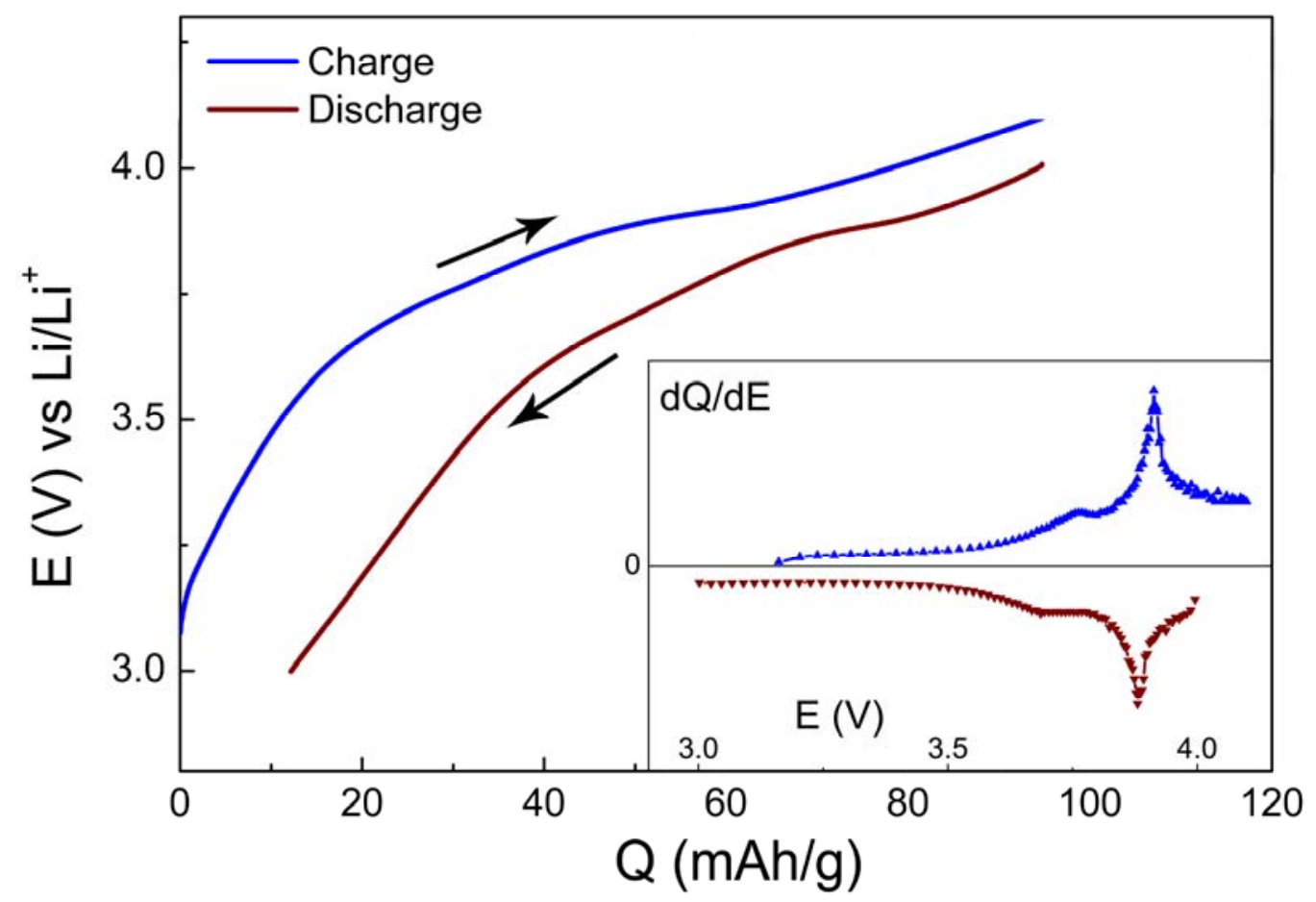

Figure 8: Constant current (CC) (dis)charge cycling between $3.0 \mathrm{~V}$ and $4.2 \mathrm{~V}(1 \mu \mathrm{A}, 0.35 \mathrm{C}$-rate) for an ALD $\mathrm{LiCoO}_{2}$ film deposited on $\mathrm{Si} / \mathrm{TiO}_{2} / \mathrm{Pt} . \mathrm{LiClO}_{4}$ in ethylene carbonate/diethyl carbonate $(\mathrm{EC} / \mathrm{DEC} 1 / 1)$ was used as liquid electrolyte. The graph displays a $12 \%$ capacity loss between charge and discharge. The used Co:Li dosing ratio was $4: 1$. The inset shows the derivative of the capacity with respect to the potential. 


\section{Electrochemical analysis}

For the electrochemical analysis, $\sim 50 \mathrm{~nm} \mathrm{LiCoO}_{2}$ was deposited on a $\mathrm{Si}$ substrate covered with an ALD synthesized $\mathrm{TiO}_{2} / \mathrm{Pt}$ stack which acts as a current collector (surface area of $2 \mathrm{~cm}^{2}$ ). The obtained $\mathrm{LiCoO}_{2}$ films were annealed at $700{ }^{\circ} \mathrm{C}$ for 6 minutes and analyzed using constant current (CC) (dis)charge cycling applying a current of $1 \mu \mathrm{A}$, i.e. $0.35 \mathrm{C}$-rate. The positive electrode reaction for $\mathrm{LiCoO}_{2}$ is shown below, in which the maximum amount of lithium that can be extracted from one $\mathrm{LiCoO}_{2}$ unit is 0.5. Extracting more than 0.5 would irreversibly change the crystal structure of $\mathrm{LiCoO}_{2}(20)$.

$$
\mathrm{LiCoO}_{2} \rightleftarrows \mathrm{Li}_{(1-x)} \mathrm{CoO}_{2}+x \mathrm{Li}^{+}+x \mathrm{e}^{-} \quad(x \leq 0.5)
$$

Figure 8 shows the (dis)charge of $\mathrm{LiCoO}_{2}$ and the inset presents the curve of the derivative of the capacity with respect to the potential. This type of plot emphasizes the reactions by transforming the plateaus into broad or sharp peaks. Using this transformation a clear reaction is made visible around $3.9 \mathrm{~V}$ for $\mathrm{LiCoO}_{2}$ as is expected from the literature $(4,7)$. Also a $12 \%$ loss in capacity between the charge and discharge reactions is found, which can be explained by the formation of a solid electrolyte interface (SEI) related to the use of a liquid electrolyte in these measurements. The lifetime of the $\mathrm{LiCoO}_{2}$ electrode was evaluated using the same constant current method and is presented in Figure 9. The electrochemical activity is lower than expected theoretically for $\mathrm{LiCoO}_{2}\left(155 \mathrm{mAh} / \mathrm{g}, 46.5 \mu \mathrm{Ah} \mu \mathrm{m}^{-1} \mathrm{~cm}^{-2}\right)$ (4), but remained fairly stable. After changing the Co:Li dosing ratio from 2:1 to 4:1 the amount of active material was increased significantly from $\sim 26 \%$ to $\sim 58 \%$ of the expected maximum storage capacity. Optimization of the $\mathrm{LiCoO}_{2}$ process is expected to further improve the storage capacity.

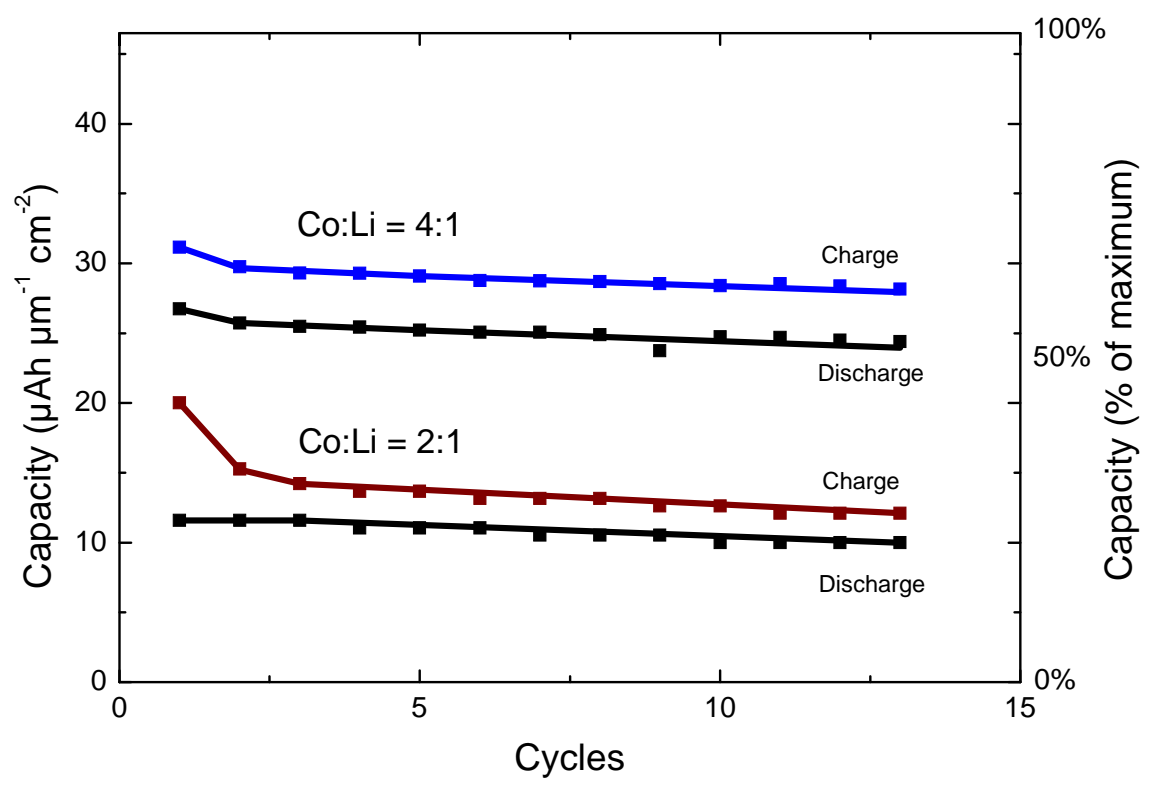

Figure 9: Capacity of a $\mathrm{LiCoO}_{2}$ electrode versus cycle number. The electrode was cycled between $3.0 \mathrm{~V}$ and $4.2 \mathrm{~V}$ at $1 \mu \mathrm{A}(0.35 \mathrm{C})$ with a half hour resting period in between the cycles. $\mathrm{LiClO}_{4}$ in ethylene carbonate/diethyl carbonate (EC/DEC 1/1) was used as liquid electrolyte. The Co:Li dosing ratio were 2:1 and $4: 1$. 
Preliminary attempts to determine the lithium concentration using ion beam analysis revealed a good correlation with the electrochemical results and could be an important new tool for the characterization of lithium-containing thin films (21).

\section{Conclusions}

A remote plasma ALD process $\left(0.06 \mathrm{~nm} /\right.$ cycle at $\left.325{ }^{\circ} \mathrm{C}\right)$ for $\mathrm{LiCoO}_{2}$ has been developed for the first time using the combination of $\mathrm{CoCp}_{2}$ as cobalt precursor, $\mathrm{LiO}^{t} \mathrm{Bu}$ as lithium precursor and $\mathrm{O}_{2}$ plasma as the oxidant source. After annealing the samples for 6 minutes at $700{ }^{\circ} \mathrm{C}$ the high temperature phase $\mathrm{LiCoO}_{2}$ is obtained as shown by XRD and Raman spectroscopy measurements. Electrochemical charge/discharge cycling experiments showed good electrochemical performance with a promising storage capacity.

\section{Acknowledgements}

This research was carried out under the project number MC3.06278 in the framework of the Research Program of the Materials innovation institute M2i (www.m2i.nl).

\section{References}

1. P.H.L. Notten, F. Roozeboom, R.A.H. Niessen, and L. Baggetto, Adv. Mater. 19, 4564 (2007)

2. J.W. Long, B. Dunn, D.R. Rolison, and H.S. White, Chem. Rev. 104, 4463 (2004)

3. D. Golodnitsky, M. Nathan. V. Yufit, E. Strauss, K. Freedman, L. Burstein, A. Gladkich, and E. Peled, Solid State Ionics 177, 2811 (2006)

4. J.F.M. Oudenhoven, L. Baggetto, and P.H.L. Notten, Adv. Energy Mater. 1, 10 (2011)

5. H. Pan, and Y. Yang, J. Power Sources 189, 633 (2009)

6. T. Brousse, P. Fragnaud, R. Marchand, and D.M. Schleich, Ionics 2, 398 (1996)

7. H. Porthault, F. Le Cras, and S. Franger, J. Power Sources 195, 6262 (2010)

8. V. Kalai Vani, and O.M. Hussain, Ionics 13, 473 (2007)

9. K.Y. Choi, K.D. Kim, and J.W. Yang, J. Mater. Processing Techn. 171, 118 (2006)

10. C. Julien, M.A. Camacho-Lopez, L. Escobar-Alarcon, and E. Haro-Poniatowski, Mater. Chem. And Phys. 68, 210 (2001)

11. J.F.M. Oudenhoven, T. van Dongen, R.A.H. Niessen, M.H.J.M. de Croon, and P.H.L. Notten, J. Electrochem. Soc. 156, D169 (2009)

12. W-G. Choi, and S-G. Yoon, J. Vac. Sci. Technol. A 22, 2356 (2004)

13. A.S. Cavanagh, Y. Lee, B. Yoon, and S.M. George, ECS Trans. 33, 223 (2010)

14. T. Aaltonen, M. Alnes, O. Nilsen, L. Costelle, and H. Fjellvåg, J. Mater. Chem. 20, 2877 (2010)

15. M.E. Donders, H.C.M. Knoops, M.C.M. van de Sanden, W.M.M. Kessels, and P.H.L. Notten, J. Electrochem. Soc. 158, G92 (2011)

16. H.C.M. Knoops, M.E. Donders, L. Baggetto, M.C.M. van de Sanden, P.H.L. Notten, and W.M.M. Kessels, ECS Trans. 25, 333 (2009)

17. E. Langereis, S.B.S. Heil, H.C.M. Knoops, W. Keuning, M.C.M. van de Sanden, W.M.M. Kessels, J. Phys. D: Appl. Phys., 42 (2009)

18. J.W. Weber, T.A.R. Hansen, M.C.M. van de Sanden, and R. Engeln, J. Appl. Phys. 106, 123503 (2009)

19. S-I. Cho, and S-G. Yoon, J. Electrochem. Soc. 149, A1584 (2002)

20. D. Danilov, and P.H.L. Notten, 5th IEEE Vehicle Power and Propulsion Conference, pp. 5289835320 (2009)

21. M.E. Donders, W.M. Arnold Bik, H.C.M. Knoops, W.M.M. Kessels, and P.H.L. Notten (2011), to be published 